\title{
Teacher Perceptions of Facilitating Inquiry-based Instruction Following a 12-month Professional Development Experience
}

\author{
M. Kreifels ${ }^{1}$, N. Conner ${ }^{2}$, B. Reiling ${ }^{3}$, C. Stripling ${ }^{4}$, M. Balschweid ${ }^{5}$
}

\begin{abstract}
Using inquiry-based learning instructional strategies as a way to integrate science into secondary classrooms is a common approach in education. This study documents agricultural teachers' perceptions of science integration using inquiry-based learning as an instructional method when teaching animal science after participating in a on professional development program. A focus group $(n=10)$ was used to collect data which were analyzed using the constant comparative method. The following six themes emerged: (a) perceived value in inquiry-based learning, (b) alignment to state and local expectations, (c) value and challenges of a 12-month program, (d) challenges in engaging science teachers, (e) confidence in teaching technical content, and ( $f$ ) integrating science concepts. Teachers in the focus group described positive experiences and attitudes when using inquiry-based learning techniques in their classrooms and described an appreciation for the 12-month program, including how the approach helped to meet state standards and local administrative requirements. Logistical challenges of a 12-month program existed, but also provided accountability for teachers. The program increased teachers' confidence in both instruction of technical content and their ability to engage students while integrating science concepts.
\end{abstract}

\section{Keywords}

Science integration, animal science, training

1. Matthew S. Kreifels, Associate Professor of Practice, University of Nebraska-Lincoln, 233 Filley Hall, Lincoln, NE 685830947, matt.kreifels@unl.edu, (D)http://orcid.org/0000-0002-6519-8711

2. Nathan Conner, Associate Professor, University of Nebraska-Lincoln, 236 Filley Hall, Lincoln, NE 68583-0947, nconner2@unl.edu, (D)http://orcid.org/0000-0002-6519-8711

3. Bryan A. Reiling, Associate Professor, University of Nebraska-Lincoln, ANSC C204a, Lincoln, NE 68583-0947, breiling2@unl.edu, (D) https://orcid.org/0000-0002-5913-0614

4. Christopher T. Stripling, Professor, The University of Tennessee, 320 Morgan Circle Drive, Knoxville, TN 37996-4511, cstripli@utl.edu, iDhttp://orcid.org/0000-0002-5045-3492

5. Mark A. Balschweid, Professor and Head, University of Nebraska-Lincoln, 143 Filley Hall, Lincoln, NE 68583-0947, mbalschweid2@unl.edu, inttps://orcid.org/0000-0002-8009-4486 


\section{Introduction and Problem Statement}

In 2015, 78\% of high school students in the United States lacked proficiency in science (Desilver, 2017), and in Nebraska, 45\% of 11th grade students lacked proficiency in science during the 2018-19 school year (Nebraska Department of Education, 2019). Traditional instruction is oftentimes reliant upon direct and unilateral instruction originating from the teacher and ending with the student, leaving students sometimes uninvolved and uninterested (Abdi, 2014) "Inquiry-based teaching is a teaching method that can be used to combine the curiosity of students and the scientific method to enhance the development of critical thinking skills while learning science" (Warner \& Myers, 2011, p.1). According to Thoron and Myers (2011) and Wells et al. (2015), inquiry-based learning assists students in the process of discovery.

Agricultural education teachers oftentimes possess a unique ability to integrate core academic subjects (math, science, reading, and language arts) into their curricula based on teaching this content within the context of the agriculture, food, and natural resources-related industries (Warner \& Myers, 2011). In a 2015 literature review focused on the infusion of inquiry-based learning, Wells et al. concluded that agricultural teachers should continuously seek out methods to integrate inquiry into their coursework. This suggestion is also supported by Parr and Edwards (2004), Phipps et al. (2008), Thoron and Myers (2011, 2012), and Washburn and Myers (2010). Additionally, Baker et al. (2000) found professional development can enhance a teacher's content knowledge level. This study aims to enhance science literacy in Nebraska by providing teachers with a rigorous professional development program that teaches science through the context of genetics, muscle biology, microbiology, and nutrition, while utilizing inquiry-based instructional practices.

\section{Theoretical and Conceptual Framework}

The conceptual framework for the 12-month professional development program and this research was Guskey's (2002) model of teacher change. Guskey's model indicates teachers alter their attitude and beliefs on a particular teaching approach after they use the approach and personally see how the approach positively impacts student learning. According to Guskey (2002), improvements in student learning outcomes "typically result from changes teachers have made in their classroom practices" (p. 383). Changes may take the form but are not limited to the use of new content/curricula or the use of different teaching methods/approaches (Guskey, 2002). The professional development experience is an example of where a teacher could be exposed to new content/curricula and teaching methods for which they are unfamiliar, and the opportunity to use their new knowledge/skill set in their own classroom allows for implementation, evaluation of student learning, and the change in beliefs and attitudes (Guskey, 2002). 


\section{Purpose}

The purpose of this case study is to describe the perceptions of agricultural teachers' science integration using inquiry-based learning as an instructional method when teaching animal science after participating in a 12-month professional development program. Research questions include:

1. How did teachers perceive the 12 -month professional development program?

2. How did teachers perceive their ability to utilize genetics, nutrition, microbiology, and muscle biology during science instruction?

3. How did teachers perceive their ability to facilitate inquiry-based instruction?

\section{Methods}

The data collected for this study were part of a larger research study. Criterion-based sampling was utilized to select participants to participate in the study, which consists of both a 12-month professional development experience and a culminating focus group interview. Participants had to be a high school agricultural or science teacher in Nebraska and complete the entire 12month professional development program. Ten high school teachers participated in this study (nine agricultural education teachers and one science teacher). This 12-month long professional development experience (July 2017-July 2018) focused on educating teachers on how to use inquiry-based learning techniques in their courses through the context of genetics, muscle biology, microbiology, and nutrition. To ensure teachers from the entire state had the opportunity to attend, three two-day sessions were delivered (western region, central region, and eastern region). Additionally, a joint one-day session was facilitated upon completion of the 12-month professional development program. Participants were expected to participate in six online video conferencing meetings using the Zoom conferencing platform. Participants were asked to incorporate four inquiry-based learning labs into their curriculum. Participants also used their new knowledge and skills to design and teach an inquiry-based lab of their own.

A case study approach was selected as the design for this study in order to more completely understand the perspectives of the participants regarding inquiry-based learning. Due to the structure of the professional development program, the researchers consider this an intrinsic case study, as it focuses on the case itself and serves well as a method of program evaluation (Creswell \& Poth, 2018). Ten teachers participated in a focus group that was conducted at the end of the 12-month professional development at a Nebraska high school and the focus group was facilitated by one of the professional development facilitators. The focus group session lasted approximately 80 minutes and utilized a semi-structured protocol. An audio recording was manually transcribed verbatim. Researchers also took handwritten notes as a form of secondary data collection that was also utilized for analysis. (Conner et al., 2014; Creswell \& Poth, 2018; Merriam \& Tisdell, 2016).

Data were analyzed using a thematic analysis method, which reduced the data in order to identify and focus on repeated phrases and words that related to the case study (Grbich, 2007). 
The constant comparative method of analysis was also employed (Merriam \& Tisdell, 2016). Open coding, axial coding, and selective coding (Corbin \& Strauss, 1990) were utilized in the coding system. Themes were identified, then reexamined, and titles were developed for each theme that emerged.

To ensure and enhance trustworthiness, triangulation and member checks were used in addition to dependability and confirmability audits (Dooley, 2007; Lincoln \& Guba, 1985). Data from the focus group were triangulated between participating investigators. Additionally, member checking was done throughout the focus group through verbal confirmation. Methodological decisions were also recorded in a journal to provide a dependability audit and a confirmability audit so findings could be connected directly to the collected data. The five researchers involved in this study include (a) two associate professors of agricultural education, (b) one associate professor of animal science, (c) one professor of agricultural education, and (d) one associate professor of practice of agricultural education who is also a doctoral student. All five researchers have between 12-18 years' experience teaching at the secondary and/or post-secondary level and strive to adapt their teaching techniques to address student needs, which may influence the choices.

\section{Findings}

The participants that completed this study were high school agricultural or science teachers in the Nebraska. For the purposes of this study, we are going to refer to the 10 participants that completed the 12-month professional development as agricultural teachers because the only science teacher was also a certified agricultural teacher.

Six themes emerged from the data, (a) value and challenges of a 12-month program, (b) challenges in engaging science teachers, (c) confidence in teaching technical content, (d) integrating science concepts, (e) alignment to state and local expectations, and ( $f$ ) perceived value of inquiry-based learning. The themes are organized by the corresponding research question and the participating teachers are labeled as "T1" through "T10".

\section{Value and Challenges of a 12-month Program (Research Question \#1)}

Multiple teachers cited the value of participating in a 12-month professional development program, in particular the accountability and continued support aspect over a schoolyear. Similar statements were made by T1, T3 and T6, which indicated that the teachers were held accountable over the course of the 12-month professional development and the program expectations were designed for the teachers to complete the entire program. Other teachers, including T7 and T8 felt that a time period of 12 months allowed them flexibility to "work the lessons in" to their curriculum. Others enjoyed the monthly Zoom group video calls between teachers, with T2 citing, "I like the Zoom [group video calls], the Zoom was easy, it was not a hard technology [service] so I liked that. It was positive," and T4 stated, "I was a first-year teacher, going into my second year, so just having that basic feedback and bouncing ideas off of each other, I think was really good for me." Many teachers also emphasized the tangible 
benefits of the 12-month program, including lesson and laboratory plans, provided supplies, equipment, stipend, and optional graduate credit.

Other teachers discussed challenges involved in a prolonged professional development experience, including the potential to strengthen the monthly Zoom group video calls. Teacher T8 expressed herself by stating, "Sometimes it felt like it was just kind of "So what have you done?", I think [the Zoom calls] could be strengthened by maybe each session having a focus question or something that we get ahead of time so that we come prepared." Others indicated that the monthly zoom calls were difficult to attend, due to a difference in time zones (T3), Wednesday evening church activities (T9), and a scheduling conflict with National FFA Convention (T7).

\section{Challenges in Engaging Science Teachers (Research Question \#1)}

Given that the project was originally intended to engage science teachers in addition to agricultural teachers, many commented on the challenges related to science teacher involvement in professional development. Many reasons surfaced, including that science teachers do not typically attend professional development during the summer months (T1, T8), the agricultural teacher was new to the school and did not feel they were in a position to encourage the science teacher to attend (T4), or that the science teacher had changed from the previous year (T1). Others suggested potential solutions, including offering, or advertising the workshops through the regional Educational Service Unit (T1, T5, T7) or by offering graduate credit (T2). Teacher T5 identified herself as a science teacher and emphasized her appreciation for the experience, saying, "I would say thank you to the [agriculture] teachers for helping to teach that also because if kids can get it more than one way, it will help them to understand the material better." Many participants agreed that more science teacher participation would be a positive addition.

\section{Confidence in Teaching Technical Content (Research Question \#2)}

An increase in confidence when teaching technical content was expressed by several teachers. Teacher T1 initially stated, "I'll be the first one to tell you, muscle biology, I don't go there because I don't know enough," however, she continued by discussing how the professional development reminded her that there are many resources that can be used to infuse muscle biology into the classroom. Teacher T7 identified herself as a younger teacher who appreciated having laboratory activities that she could add to her courses rather than solely rely on "textbook learning." Conversely, Teacher T5 identified herself as someone who's been teaching for a long time and someone who often teaches a concept the same way each time because that is how she has always taught it. Additionally, T5 appreciated the curriculum that this professional development provided because it boosted her confidence.

Teachers also emphasized the benefit of university animal scientists as resources that empowered them to teach technical content with more confidence. Teacher T2 stated, "I would have Dr. [university animal scientist] do more as he's an expert and [all] his comments he was giving throughout were worthwhile, critiquing our lessons, into more of the science side," adding, "But more comments about this is what we're doing at the University, this is an 
application of what your lesson is, [helps] to reinforce that [what] we're teaching is correct." Others agreed that expert presence and university involvement increased the relevance of the content with students $(\mathrm{T} 1, \mathrm{~T} 7)$.

\section{Integrating Science Concepts (Research Question \#2)}

Based on participation in the professional development program, teachers described how they were able to integrate science concepts into their classes. Teacher T7 stated, "It made me think a lot more about forcing students to [do] some research and come back with an answer the next day, ... whereas sometimes I maybe struggled with that in the past." Teacher T8 agreed, saying, "when I went through UNL, I had to take more science classes ... so I knew this information but some of it I hadn't taught for a while-just because I don't teach science every day." It's good to bring [science] it back to my classroom and refresh a little bit" (T8). Others were more explicit, including Teacher T1, explaining, "I knew how it [science] connected to animals and, you know, digestion and this is how the stomach works, and this is how it breaks it down, but now I know more of the science behind it." She went on to describe how that impacted what she shared with students, stating,

[Because] I knew more of the science behind it, I didn't just kind of gloss over that and talk about strictly the animal and the digestive tract, but I was able to go into the science, so I would say [my integration of science] was better than it was.

Others described how integrating science into their classes helped to connect their content to that from other classes, including the scientific method (T6), independent/dependent variables and graphing (T2), and scientific vocabulary $(\mathrm{T} 2, \mathrm{~T} 6, \mathrm{~T} 7)$. Teacher $\mathrm{T} 8$ summarized the ability to support other scientific content as follows,

So I think this is where, we as [agriculture] teachers have a really cool opportunity, I have students that come to my classroom and they've already learned about genetics, maybe in biology class, but they haven't got to do anything hands-on or apply that. Really, so a lot of times, like when I taught this genetics lesson, it was like a brief refresher, they knew how to do Punnett squares, they knew all of that, but they hadn't done any sort of hands-on inquiry-based lab and so I was able to spend my time doing that just to reinforce something that they had already learned. And we have the opportunity to do that I think a little bit more in the [agriculture classroom].

Some teachers identified ways that integrating science benefited the critical thinking process of students, including Teacher T1, who said, "So giving them an outlet to be able to communicate that and realize that science is not always a black or white answer, like there's a lot of gray areas, and there's not really a wrong answer necessarily." Teacher T3 discussed how students struggle to effectively justify their findings, while Teacher T8 described how her students tested more than one variable in an experiment and then were not able to determine which variable was responsible for tenderizing the meat. She added, "I think by letting them make that mistake, and then if I would've had time, go back and do the lab again, reinforcing that you want to have just one variable would've been good."

While many benefits of integrating science were discussed, challenges were also identified, including a reluctance of students to complete laboratory reports thoroughly $(T 1, T 4, T 5, T 7)$, 
hesitance to diagnose possible errors in an experiment (T5), and difficulty using scientific literature as a resource $(T 2, T 7)$. Teacher $T 2$ indicated that there is not enough time to have students connect their findings to science experiments that have already been done.

\section{Alignment to State and Local Expectations (Research Question \#2 and \#3)}

Several teachers discussed how both the focus on science content and integration within the agricultural lessons in addition to inquiry-based instruction addressed local school and state expectations. Teacher T5, who teaches science, noted that "Inquiry is such a new, or big - huge part of the new standards and so, [I enjoy] facilitating the use of more of that in my classroom." She extended her thought, stating,

...the new science standards are heavily inquiry-based and the new science assessment that'll come about 2021 ... may have a text dependent analysis component, so to push yourself to have kids analyze data and analyze a research project and things is good for them.

Teachers also agreed that they can help to meet state and local requirements, including local curricular requirements, including stated learning objectives (T6), approved teaching methods (T2), and helping prepare students for the ACT exam through the use of vocabulary (T7).

\section{Perceived Value of Inquiry-Based Learning (Research Question \#3)}

Teachers that participated in the 12-month professional development program felt that learning and practicing inquiry-based learning as a teaching method was a strength of the program. Teacher T8 said:

...we get so busy in teaching and kind of sometimes it feels like you get into a rut of doing the same thing or just surviving sometimes. And so to have this to challenge you or challenge me to do more inquiry, you know, kind of just brought it back. I've done it in the past but it kind of brought it to the forefront and I'm going to say forced me to do more of it, which is good."

Teacher T4 appreciated a different approach as a second-year teacher, saying:

I think that first year was really more, you know, book discussion and lecture type thing. And part of [it is] different types of classes because I didn't have any animal science lessons my first year, but going into this and having to think about the inquiry-based lessons and trying to keep myself from just guiding them down the path every lesson and letting them work through some of the questions and materials at times, rather than being their shepherd."

Conversely, Teacher T6, who had experience with inquiry-based learning emphasized the accountability of the 12-month program, saying, "I think this [professional development] helped a lot with learning how to do inquiry because a lot of other [professional development], they touch on it and they give you lessons and they're like [this professional development] here, do this". Additional teachers also felt that the professional development taught them how to use inquiry in their courses, with T3 and T7 emphasizing how the focus on inquiry-based learning in one course encouraged them to think about how they approach content and instruction in other courses. 
Some teachers felt that inquiry-based learning did present some challenges, citing a difficulty when teaching multiple ages or grade-levels in the same class. Teacher T8 stated, "I had different ages in the same class and I found that the seniors actually struggled the most with inquiry because they haven't had to do it, and they just want spoon fed." However, "the younger kids seem to do better with it, and so having that mix in the classroom was a little bit different and difficult and made it hard" (T8). Teacher T3 discussed the possible advantages of including difficult content for younger students, including the potential to "expose [students] to what's taking place in the digestive system, which sparks their interest for some higher-level [thinking] in some of the classes, such as vet science and so forth."

\section{Conclusions, Discussion, and Recommendations}

\section{Research Question \#1}

The 12-month nature of the professional development program that spanned an entire school year allowed teachers to slowly integrate these practices over time. Integration of inquirybased lesson into teachers' classrooms over a one-year period aligns with Guskey's (2002) model of teacher change. Teachers had the opportunity to teach using the new content and inquiry-based learning method at least five times over the year. Then, they were able to evaluate how the new content and teaching method impacted student learning in their classroom (Guskey, 2002). When considering the longitudinal nature of a 12-month program, teachers identified both positive and challenging aspects, including accountability and flexibility to implement the lessons in addition to difficulties involved in scheduling monthly group video calls. Additionally, given the 12-month length of the program, the online zoom meetings may be better timed to accommodate as many teachers' schedules as possible and by having a clearly defined purpose with assignments that help prepare the teachers to continue to move forward.

\section{Research Question \#2}

Teachers described an increased confidence in their ability to teach technical content in agriculture, crediting access to prepared lesson materials and university expert support. Finally, teachers also indicated an increased ability and appreciation for the integration of science concepts, including helping students connect to science content taught in other classes and the development of critical thinking skills, as previously supported by Warner and Myers (2011).

\section{Research Question \#3}

The professional development program successfully helped agricultural teachers gain knowledge and skills that were used in their classrooms to facilitate inquiry-based instruction. Using Guskey's (2002) model to design the 12-month professional development created an environment where teachers engaged students in their classrooms with scientifically oriented questions and required students to collect evidence and make decisions. This inquiry-based process aligned with Pedaste et al.'s (2015) visualization of inquiry-based learning. The focus of infusing inquiry-based learning into the classroom also helped to meet the call of researchers 
that posit that agricultural teachers should regularly use inquiry-based learning in their courses (Parr \& Edwards, 2004; Phipps et al., 2008; Washburn \& Myers, 2010; Wells et al., 2015).

Some teachers found difficulty with getting students to formulate explanations after summarizing evidence that was collected. Integration of the inquiry-based teaching method into the teachers' classrooms gave the teachers the opportunity to critically examine how learning outcomes were impacted, thus shaping the teachers' attitudes and belief towards the inquiry-based learning method (Guskey, 2002). Advancements can also be made to help teachers facilitate and critique student connections to scientific knowledge, noting specifically that teachers and students did not utilize scientific or peer-reviewed journals as sources of information.

Future professional development trainings should be modified to help teachers equip students to reflectively formulate explanations and utilize scientific literature. Further research should be conducted to capture student perception of inquiry-based learning as a teaching method, how scientific content is utilized within an agricultural course, resistance to inquiry-based learning due to students' responsibility to find answers, challenges in using inquiry-based learning in classes with mixed grade levels, and the ability for inquiry-based learning to make science concepts relevant by giving students choice in the context of their learning.

\section{Acknowledgements}

We would like to acknowledge and the thank Nebraska's Coordinating Commission for Postsecondary Education for funding this research.

\section{References}

Abdi, A. (2014). The effect of inquiry-based learning method on students' academic achievement in science course. Universal Journal of Educational Research, 2(1), 37-41. https://doi.org/10.13189/ujer.2014.020104

Baker, D. L., Lewis, E. B., Uysal, S., Purzer, S., Lang, M., \& Baker, P. (2011). Using the communication in science inquiry project professional development model to facilitate learning middle school genetics concepts. Professional Development in Education, 37(3), 453-468. https://doi.org/10.1080/19415257.2010.509945

Berg, B. L. (2001). Qualitative research methods for the social sciences. Allyn and Bacon.

Conner, N. W., Rubenstein, E. D., Dibenedetto, C. A., Stripling, C. T., Roberts, T. G., \& Stedman, N. L. (2014). Examining student perceptions of flipping an agricultural teaching methods course. Journal of Agricultural Education, 55(5), 65-77. https://doi.org/10.5032/jae.2014.05065 
Corbin, J., \& Strauss, A. (1990). Grounded theory research: Procedures, canons, and evaluative criteria. Qualitative Sociology, 13(1), 3-21. https://doi.org/10.1007/BF00988593

Creswell, J. W., \& Poth, C. N. (2018). Qualitative inquiry and research design: Choosing among five approaches (4th ed.). Sage.

Desilver, D. (2017). U.S. students' academic achievement still lags that of their peers in many other countries. Pew Research Center. https://www.pewresearch.org/facttank/2017/02/15/u-s-students-internationally-math-science/

Dooley, K. E. (2007). Viewing agricultural education research through a qualitative lens. Journal of Agricultural Education, 48(4), 32-42. https://doi.org/10.5032/jae.2007.04032

Grbich, C. (2007). Qualitative data analysis: An introduction. Sage.

Guskey, T. R. (2002). Professional development and teacher change. Teachers and Teaching, 8(3), 381-391. https://doi.org/10.1080/135406002100000512

Lincoln, Y. S., \& Guba, E. G. (1985). Naturalistic inquiry. Sage.

Merriam, S., \& Tisdell, E. J. (2016). Qualitative research: A guide to design and implementation (4th ed.). John Wiley and Sons.

Nebraska Department of Education. (2019). Nebraska public schools state snapshot [Sciencepercent proficient by grade]. https://nep.education.ne.gov/State/Index/00-0000$\underline{000}$ ?DataYears $=20182019 \&$ type=state\#nesa-scores

Parr, B. A., \& Edwards, M. C. (2004). Inquiry-based instruction in secondary agricultural education: Problem-solving - An old friend revisited. Journal of Agricultural Education, 45(4), 106-117. https://doi.org/10.5032/jae.2004.04106

Phipps, L. J., Osborne, E. W., Dyer, J. E., \& Ball, A. (2008). Handbook on agricultural education in public schools (6th ed.). Sage.

Thoron, A. C., \& Myers, B. E. (2011). Effects of inquiry-based instruction on student achievement. Journal of Agricultural Education, 52(4), 175-187. https://doi.org/10.5032/jae.2011.04175

Thoron, A. C., \& Myers, B. E. (2012). Effects of inquiry-based agriscience instruction on student scientific reasoning. Journal of Agricultural Education, 53(4), 156-170. https://doi.org/10.5032/jae.2012.04156

Warner, A. J., \& Myers, B. E. (2011). What is inquiry-based instruction? IFAS Extension. https://edis.ifas.ufl.edu/pdffiles/WC/WC07500.pdf 
Washburn, S. G., \& Myers, B. E. (2010). Agriculture teacher perceptions of preparation to integrate science and their current use of inquiry-based learning. Journal of Agricultural Education, 51(1), 88-98. https://doi.org/10.5032/jae.2010.01088

Wells, T., Matthews, J., Caudle, L., Lunceford, C., Clement, B., \& Anderson, R. (2015). The infusion of inquiry-based learning into school-based agricultural education: A review of literature. Journal of Agricultural Education, 56(4), 169-181.

https://doi.org/10.5032/jae.2015.04170

(C) 2021 by authors. This article is an open access article distributed under the terms and conditions of the Creative Commons Attribution license (http://creativecommons.org/licenses/by/4.0/). 